Int. J. Plant Sci. 165(5):723-738. 2004.

(c) 2004 by The University of Chicago. All rights reserved.

$1058-5893 / 2004 / 16505-0003 \$ 15.00$

\title{
FLORAL MORPHOLOGY AND DEVELOPMENT IN ARAGOA (PLANTAGINACEAE) AND RELATED MEMBERS OF THE ORDER LAMIALES
}

\author{
M. A. Bello, * P. J. Rudall,† F. González, ${ }^{1, *}$ and J. L. Fernández-Alonso* \\ *Facultad de Ciencias, Universidad Nacional de Colombia, Ap. Ae. 7495 Bogotá; and †Jodrell Laboratory, \\ Royal Botanic Gardens, Kew, Richmond, Surrey TW9 3AB, United Kingdom
}

\begin{abstract}
Inflorescence and floral morphology and development were investigated in Aragoa (Plantaginaceae) and related genera. Each inflorescence of Aragoa is a reduced, axillary raceme, on which the actinomorphic floral apices generally arise successively. The inflorescences of Aragoa and Plantago are polytelic and lateral. The five sepals emerge from the abaxial to the adaxial side of the floral apex, but at maturity, the calyx is actinomorphic. The four stamens arise simultaneously and before emergence of the petals. The four petals emerge unidirectionally united, but the corolla becomes actinomorphic. Aestivation is cochlear ascendent. The two united carpels initiate simultaneously. The abaxial-adaxial inception of the calyx and corolla during early floral development in genera such as Aragoa, Digitalis, Plantago, and Veronica may indicate that the zygomorphic condition is ancestral in those genera. The tetramerous corolla, which is actinomorphic during middle and late development, and the presence of four stamens are possible synapomophies of the clade $($ Aragoa + Plantago $)$. Pentamery of the calyx and corolla appears to be plesiomorphic in the broader AragoaAngelonia clade. Characters related to development and morphology of inflorescences and flowers of Aragoa are essentially similar to those found in Plantago, which is consistent with the molecular-based sister group relationship between these genera.
\end{abstract}

Keywords: Antirrhinum, Aragoa, floral development, floral morphology, Heliohebe, Lamiales, Plantago, Plantaginaceae, "Scrophulariaceae," Veronica.

\section{Introduction}

Aragoa Kunth, with 19 species, three subspecies, and four probable hybrids (Fernández-Alonso 1995), is endemic to the páramos of Colombia and Venezuela, between 2500 and $4000 \mathrm{~m}$ altitude (Pennell 1937; Fernández-Alonso 1991, 1993, 1995; Nilsson and Hong 1993). The genus was originally described as "Bignoniaceis affinia" by von Humboldt et al. (1819), but its affinities have been in dispute since then (for review, see Fernández Alonso 1995; Bello et al. 2002).

Before recent molecular analyses, most authors included Aragoa within Scrophulariaceae sensu lato (e.g., Endlicher 1836-1840; Wettstein 1895; Fernández-Alonso 1995), closely related to genera such as Hebe Comm. ex Juss. and Veronica L. in tribe Veroniceae (Bentham 1846, 1876; Hallier 1903; Pennell 1937; Yamazaki 1957; Thieret 1967; Nilsson and Hong 1993). However, Aragoa is atypical among Scrophulariaceae sensu lato because all species are shrubs or small trees and have actinomorphic corollas. These characters states led Pennell (1937) to regard Aragoa as primitive Veroniceae. Other characters of Aragoa, such as the helicoid arrangement of the leaves, the presence of four equal stamens, and the morphology of pollen and seed (Thieret 1967; Nilsson and Hong 1993), are not shared with all other members of the former

${ }^{1}$ Author for correspondence; e-mail fagonzalezg@unal.edu.co.

Manuscript received September 2003; revised manuscript received March 2004. tribe Veroniceae. Nilsson and Hong (1993) separated the genus into its own tribe (Aragoeae) based on pollen morphology but did not clarify its closest relationships within Scrophulariaceae. Fernández-Alonso (1995) observed some morphological similarities with Capraria L., Chionohebe Briggs \& Ehrend., Detzneria Schltr. ex Diels., and Hebe and Scoparia L. but did not clearly propose a close relationship with any of them.

Several authors have used floral characters to discuss the systematic relationships of Aragoa. For example, Don (1835) segregated the genus into its own family Aragoaceae based on the "convolute" aestivation of the corolla, later described by Bentham (1846) as imbricate. Others (Meisner 1830-1843; Endlicher 1836-1840; Bentham 1846; Rouy 1909) placed the genus within tribe Veroniceae, primarily on the basis of characters such as its racemose inflorescence, five-lobed calyx, the imbricate aestivation of the four-lobed corolla with funnelrotate shape, and the tetramerous androecium with confluent thecae. Although floral morphology has provided key characters in assessments of the systematic relationships of the genus, a detailed study of its floral development and morphology is lacking, preventing a comparison with related genera that have already been investigated (see, e.g., Payer 1857; Chatin 1873; Saunders 1933; Srinivasan 1940; Yamazaki 1957; Schrock and Palser 1967; Singh 1979; Singh and Jain 1979; Nishino 1983; Awasthi et al. 1984; Leins and Erbar 1988; Endress 1992, 1994, 1998; Wunderlin 1992; Kampny et al. 1993; Kampny and Dengler 1997; Prakash and Singh 1997).

Recent molecular and phytochemical data for Aragoa support a previously unsuspected sister group relationship with 
Plantaginaceae, which resulted in the inclusion of Aragoa within Plantaginaceae (Bello et al. 2002; Rønsted et al. 2002; Jensen et al. 2003), with Veronica as its immediate sister group. The aims of this article are to investigate the floral development and morphology of Aragoa and to compare these results with those of genera that are currently included in the clade recognized by Bello et al. (2002), hereafter called the Aragoa-Angelonia clade (Veronicaceae sensu Olmstead et al. 2001). The hierarchical structure of this clade is as follows: (()((()(Aragoa + Plantago $)$ Veronica $)$ Hemiphragma $)$ Digitalis) Globularia) (Callitriche + Hippuris) Antirrhinum) ((Chelone + Collinsia $)$ Tetranema $)$ and other genera of its sister clade (((Amphianthus + Gratiola) Bacopa) Angelonia). Heliohebe Garn.-Jones, a member of the Hebe complex sensu Garnock-Jones (1993), and Littorella, a basal genus in the phylogeny of Plantaginaceae s.l. (Rønsted et al. 2002; Hoggard et al. 2003), are here treated as distinct genera in the discussion of floral characters.

The inclusion of Aragoa in a clade with Antirrhinum, Plantago, and Veronica makes examination of its floral morphology and ontogeny particularly relevant because recent developmental-genetic work on floral symmetry in Antirrhinum has demonstrated that zygomorphy relies on differential expression of two closely related adaxial identity genes CYCLOIDEA (CYC) and DICHOTOMA (DICH) in the young floral meristem (Coen and Nugent 1994; Coen 1996; Luo et al. 1996, 1999). This discovery has stimulated a renaissance in studies of floral symmetry patterns (e.g., Neal et al. 1998; Endress 1999; Rudall and Bateman 2003). Plantago is often cited as an example of a taxon with actinomorphic flowers that is phylogenetically nested within a clade with taxa that produce predominantly zygomorphic flowers (Coen and Nugent 1994; Donoghue et al. 1998; Endress 2003). Because flowers of Aragoa are also regarded as actinomorphic, such different patterns of symmetry in related taxa would merit more rigorous examination in this clade.

\section{Material and Methods}

Floral buds of Aragoa and Plantago were collected in the field at several stages of development, whereas those of Heli- obebe raoulli were collected from the living collections at the Royal Botanic Gardens, Kew. Various developmental stages covering the complete floral ontogeny of four species (two of them from three different populations) and one putative hybrid of Aragoa were examined under the LM and SEM (vouchers cited in table 1). Samples were fixed in FAA and then transferred to $70 \%$ ethanol. The samples were then dissected in 90\% ethanol under a Wild Heerburg M8 dissecting microscope. The material was then submitted to a dehydration series of $90 \%, 95 \%$, and $100 \%$ ethanol, $1 \mathrm{~h}$ in each concentration. The samples used for SEM were critical point dried in a Balzers 030 drier, coated with gold in an Emitech Sputter coater K550, and examined and photographed on a Cambridge Instruments Stereoscan 240 at $15 \mathrm{kV}$. For light microscopy, the samples were transferred from 100\% ethanol through an ethanol-Histoclear series $(90: 10,70: 30$, $50: 50,30: 70,10: 90,0: 100)$ for $18 \mathrm{~h}$. Floral buds were embedded in paraplast for serial sectioning using a rotary microtome (Reichert-Jung 2040). Sections were stained with safranin and Alcian Blue and mounted in DPX resin.

\section{Results}

\section{Organography of Aragoa}

The flowers of Aragoa are bisexual (fig. 1). The five sepals are ovate, oblong, or lanceolate; equally sized (ranging from 2.8 to $8 \mathrm{~mm}$ long), (sub)coriaceous, frequently with long hairs on the margin and short hairs along the dorsal side. By preanthesis, the calyx shows a cochlear-ascendent aestivation (figs. $2,3 N$ ). The corolla is tetramerous, actinomorphic, rotate (e.g., in Aragoa cundinamarcensis Fernández-Alonso) to subrotate (e.g., in Aragoa abietina H.B.K., Aragoa cleefii FernándezAlonso, and Aragoa cupressina H.B.K.) or tubular-campanulate (e.g., Aragoa perez-arbelaeziana Romero). The corolla is generally white, except in the yellow-flowered $A$. perez-arbelaeziana). The tube is $1.5-17 \mathrm{~mm}$ long, and the corolla lobes are obovate or spathulate, 3 to $9 \times 2.5$ to $7 \mathrm{~mm}$ (fig. 1 ). The marginal indumentum of the petals is different in the species studied. In A. cleefii and A. cupressina H.B.K., it is formed by dense filiform hairs (fig. 4C); in Aragoa x funzana Fernandez-Alonso,

\section{Table 1}

Species and Material Examined

\begin{tabular}{|c|c|c|}
\hline Species & Voucher & Locality \\
\hline Aragoa abietina Kunth & COL: Bello 118, 119, 120 & $\begin{array}{l}\text { Colombia: Cundinamarca, Parque Nacional } \\
\text { Natural Chingaza }\end{array}$ \\
\hline Aragoa cleefii Fernández-Alonso & COL: Bello 108 & $\begin{array}{l}\text { Colombia: Cundinamarca, Villapinzón, Páramo } \\
\text { de Gachaneque }\end{array}$ \\
\hline Aragoa cundinamarcensis Fernández-Alonso & COL: Bello 107 & $\begin{array}{l}\text { Colombia: Cundinamarca, Villapinzón, Páramo } \\
\text { de Gachaneque }\end{array}$ \\
\hline Aragoa cupressina Kunth & COL: Bello 128, 129, 130 & Colombia: Cundinamarca, Páramo de Monserrate \\
\hline Aragoa x funzana Fernández-Alonso & COL: Bello 113, 115 & $\begin{array}{l}\text { Colombia: Cundinamarca, Villapinzón, Páramo } \\
\text { de Gachaneque }\end{array}$ \\
\hline Heliohebe raoulli (Hook.f.) Garn.-Jones & HK: 1996-23; CHAD 574 & Royal Botanic Gardens, Kew \\
\hline Plantago major L. & COL: Bello 247 & Colombia: Bogota, campus of the National University \\
\hline
\end{tabular}

Note. $\mathrm{COL}=$ specimen supported by a voucher in the Colombian National Herbarium, Bogota. HK = material collected from the Living Collections, Royal Botanic Gardens, Kew. 

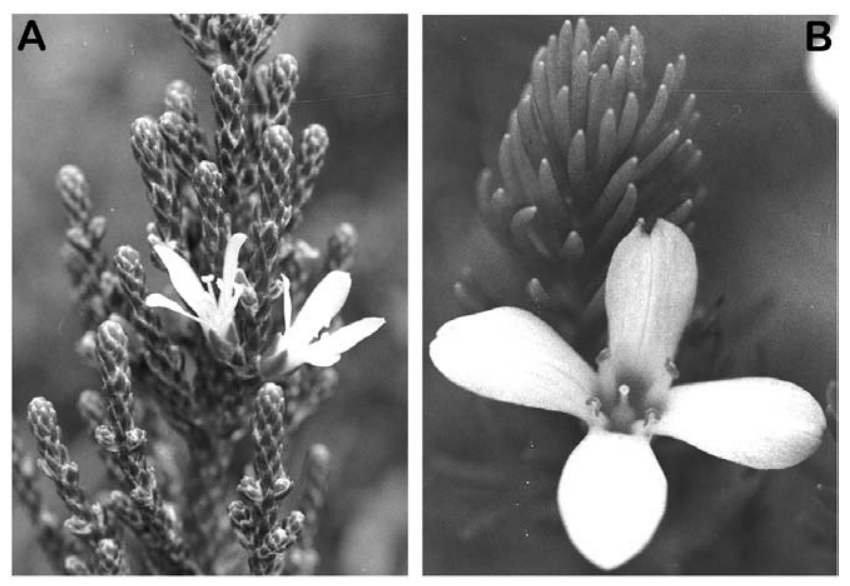

Fig. 1 Flowering shoots of Aragoa

the hairs are scarce, whereas petal margins of A. abietina are glabrous. The corolla aestivation is cochlear ascendent (fig. $4 A$, $4 B$; fig. $5 H)$.

The four epipetalous stamens alternate with the corolla lobes (fig. 4G) and have filiform, glabrous, or distally pubescent filaments (fig. 5E, 5G) and dithecal, dorsifixed, short (0.7-1.8 $\mathrm{mm}$ long) anthers that are introrse and open by longitudinal slits (fig. 4G). The gynoecium is bottle shaped, bilocular, and basally surrounded by a hypogynous, ringlike nectariferous disc (fig. 4F, 4G; fig. 5C, 5J). Placentation is axile, and there are four to eight ovules per locule (figs. $4 F, 5 J$ ). The style is cylindrical, up to $20 \mathrm{~mm}$ long, reaching the same level of the anthers by anthesis (figs. $1 B, 4 G$ ). The stigma is slightly bilobed, capitate, dry, and papillate (fig. 4I).

\section{Floral Development of Aragoa}

Inflorescences. The inflorescences of Aragoa are reduced axillary racemes, which are often congested in adjacent nodes of the distal or middle zones of the branches. The racemes and internodes are both extremely short, resulting in a floral arrangement that appears whorled. Several floral pseudowhorls can develop along a single branch, but they are separated by a long vegetative zone. The youngest racemes are closest to the branch apex, which suggests an acropetal sequence of development (fig. 1A). Each raceme is subtended by a leaf and consists of two or three flowers (figs. $1 A, 2$ ). If the raceme has three flowers (e.g., in A. cundinamarcensis, A. cupressina, and A. x funzana), two of them are lateral, and one occupies the median position (fig. 2). Each flower is subtended by a single leaflike bract. This bract is perpendicularly oriented with respect to the subtending leaf in the lateral flowers and opposite to it in the median flower. Within each inflorescence, floral apices generally arise successively, but two can occasionally initiate almost simultaneously (fig. $3 A, 3 B)$. Simultaneous emergence of three floral apices within the same inflorescence was not observed. A dense indumentum of white hairs surrounds the buds, especially during early stages of development (fig. $3 A$ ).

Calyx. The floral apex is initially radially symmetrical (fig. 3A). Calyx development commences with the simulta- neous initiation of the two abaxial-lateral sepals, followed by initiation of the two adaxial-lateral ones. The gap between the latter two is soon filled by the fifth (adaxial) sepal primordium (fig. 3B-3D). Thus, the emergence of the sepals is unidirectional, from the abaxial to the adaxial side of the floral apex, indicating a zygomorphic initiation of the calyx. The abaxial-lateral sepals are slightly larger than the adaxiallateral ones, whereas the adaxial sepal is the smallest (fig. $3 E, 3 N)$; this difference remains evident until preanthesis. The formation of the calyx tube is slightly asymmetric because intercalary growth between the abaxial-lateral sepals occurs earlier than that between the lateral and the adaxial sepals (fig. 3F). By preanthesis, the calyx becomes actinomorphic and has cochlear-ascendent aestivation. Sepals have a dense covering of hairs along the margins.

Androecium and corolla. The four stamens primordia arise simultaneously opposite to the abaxial-lateral and the lateral sepals, before the emergence of the alternating petal primordia (fig. 3G). There is no evidence of a fifth stamen opposite the adaxial sepal. Initiation of the four petal primordia is unidirectional because the abaxial and the lateral petal primordia emerge simultaneously alternating with the sepals, and the adaxial initiates later opposite the adaxial sepal (fig. $3 H$ ). Then, the emergence of the petals results in initial bilateral symmetry for the corolla. Just after organogenesis, the petal primordia are separated from each other by the developing stamens (fig. 3I-3K). Late sympetaly occurs by growth subjacent to the petals and their sinuses. The stamens in these sinuses thus fuse to the corolla (fig. $3 I, 3 K, 3 L$ ). At this time, differentiation of filament and anther becomes apparent, and the corolla is slightly zygomorphic (fig. $3 \mathrm{~L}, 3 \mathrm{M}, 3 \mathrm{O}$ ).

Before anthesis, corolla aestivation becomes cochlear ascendent as the lateral and abaxial lobes enlarge over the adaxial one (fig. 4A-4C). Corolla aestivation in the lateral flowers within an inflorescence forms mirror images (cf. fig. 4A, 4B). By anthesis, the corolla becomes actinomorphic after the

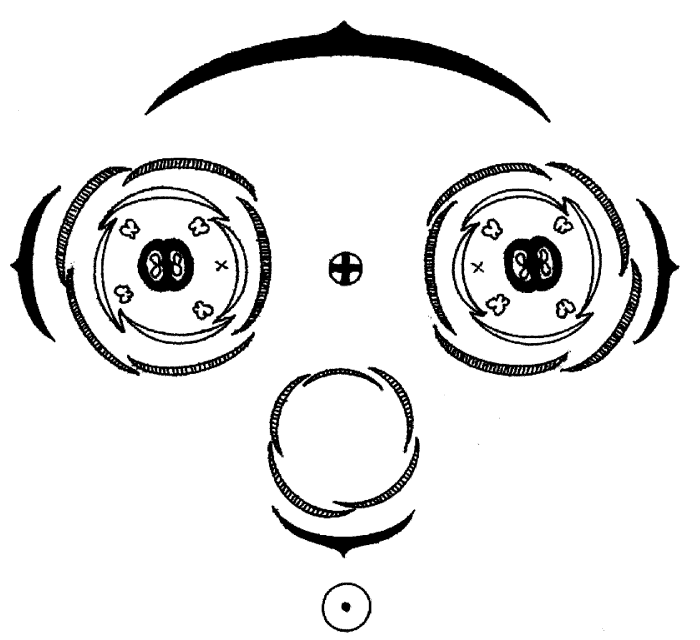

Fig. 2 Inflorescence diagram of Aragoa with the two lateral flowers already developed and a third floral apex in median position. Subtending leaf and bracts are in black; sepals are hatched; petals are in white; circle with dot represents shoot axis; circle with cross represents inflorescence axis. 

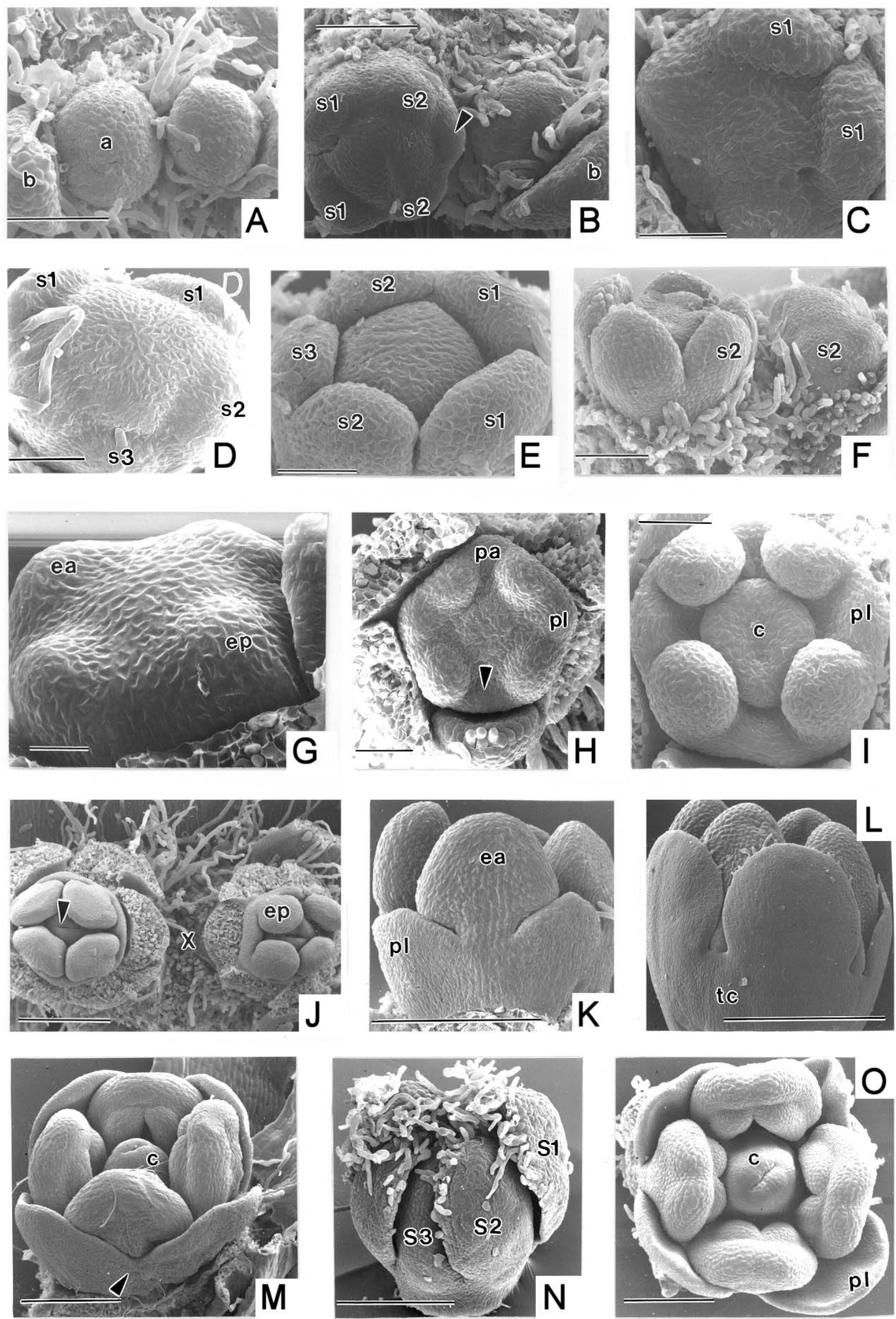
enlargement of petals and the tube, and the four stamens are fully developed and alternate with the corolla lobes (fig. 1).

Gynoecium. After petal initiation, a gynoecium primordium in the center of the young flower is apparent (fig. $3 H$ ). Shortly after that, the congenitally fused carpels appear as a ringlike primordium, without protruding median parts (i.e., symplicate carpels); the septum develops later (fig. $3 H, 3 I$ ). The carpels remain united up to the stigmatic region, where there is a narrow furrow radially oriented with respect to the axis of the inflorescence (fig. 3J, 3O). A narrow style with a central transmitting tract (fig. $5 E, 5 F, 5 H, 5 J$ ) is formed after elongation of the upper part of the pistil.

\section{Floral Vasculature and Anatomy of Aragoa}

Serial cross sections of Aragoa flowers (fig. 5) show that the vascular traces along the pedicel form a continuous stele. At the level of calyx insertion, the median vascular trace of each sepal departs directly from the central stele and remains unbranched (fig. 5A-5E). Additionally, five commissural bundles depart from the stele, and each divides into two traces at the base of the sepals, forming the two lateral traces of adjacent sepals (fig. 5A). As a result, each sepal contains three main vascular bundles.

At the level of insertion of the corolla, eight vascular traces depart from the central stele, four of which supply the corolla and the alternating four supply the stamens (fig. $5 \mathrm{~B}-$ $5 E)$. At this level, the adaxial petal trace divides into three traces; the median of these three traces enters the center of the adaxial corolla lobe, and the two lateral traces irrigate its flanks. The two median carpellary veins are also evident at the level of corolla insertion (fig. $5 \mathrm{~B}, 5 \mathrm{C}$ ). A short distance above this level, each of the two remaining petal traces also splits into three traces. These traces essentially have the same branching pattern as the adaxial trace. The central traces of each petal further divides into five to eight traces in the distal half of each corolla lobe. In contrast, stamen bundles remain unbranched (fig. 5D, 5E).

The remaining central vascular traces supply the gynoecium. Each of the two carpels is irrigated by a median and two lateral bundles. The ovules are directly supplied by the marginal traces. There are two traces along the style (fig. $5 F$ ).

Glandular trichomes consisting of a stalk of two to three cells and a head formed by six cells are scattered on both the outer and the inner corolla surfaces (fig. 4D, 4E, 4H); they are restricted to the distal part of the tube in some species (e.g., A. cupressina). In contrast to the thick cuticle present in mature sepals, petals lack cuticle, at least in some species (fig. 5). The inner epidermis of the petal consists of a single layer of domed (papillate) cells; a dense covering of filiform hairs is also present at the level of stamen insertion (fig. 4G). Stomata were observed on petal surfaces in all species examined. The petal mesophyll consists of a homogeneous parenchyma without intercellular spaces (fig. 5E, 5G, 5H).

The epidermis of the anthers is formed by a thin layer, and the endothecium consists of regularly shaped cells with thickened walls near the dehiscence area. The tapetum is parietal.

\section{Floral Development of Heliohebe}

Inflorescence. Inflorescences of Heliobebe raoulii are terminal racemes, in which flowers develop spirally and acropetally (fig. 6A). A single bract covers the corresponding floral bud by the time of emergence of the abaxial-lateral sepals.

Calyx. The floral apex is zygomorphic (fig. 6A). The two abaxial-lateral sepal primordia initiate first. They emerge simultaneously. The two adaxial-lateral sepals arise much later (fig. 6B, 6C); they also emerge simultaneously and remain smaller than the abaxial-lateral sepals throughout development (fig. 6C-6F). The whole calyx is therefore zygomorphic. There is no evidence of a fifth sepal primordium. The fusion between the abaxial-lateral sepals is greater than that between the adaxial-lateral ones (fig. 6D-6F). The flanks of the abaxial-lateral sepals partially overlap the adaxial-lateral sepals (fig. 6C-6F). Marginal trichomes become evident on the abaxial-lateral sepals during late development.

Androecium and corolla. During development, these floral whorls are highly zygomorphic in $H$. raoulii. The two stamen primordia initiate simultaneously after the emergence of adaxial-lateral sepals (fig. 6C), opposite them. There is no evidence of additional stamen primordia. Later, three petal primordia simultaneously emerge on the abaxial side of the floral bud; the abaxial petal primordium alternates with the two abaxial-lateral sepals and the two lateral petal primordia opposite them (fig. 6D). Petal growth is delayed because lobes are still included in the young flower even during late development (fig. 6E, 6F). By preanthesis, the corolla aestivation is imbricate because the two lateral petals are external to the medial petals (not shown).

Gynoecium. The gynoecium primordium in the center of the young flower appears to initiate simultaneously with petal initiation. Shortly after that, the congenitally fused

Fig. 3 Early and midfloral development of Aragoa. A, Aragoa cundinamarcensis. Two floral apices. B, Aragoa x funzana. Upper view of inflorescence apex (arrowhead points to primordium of adaxial sepal). C, Aragoa cleefii. Floral bud with the abaxial-lateral sepals initiating first. D, Aragoa cundinamarcensis. Unidirectional development of sepals. E, Aragoa cleefii. Calyx before stamen emergence. F, Aragoa cundinamarcensis. Lateral view of inflorescence. G, Aragoa cupressina. Stamen emergence. H, Aragoa cundinamarcensis. Upper view of floral bud (sepals removed except the adaxial one); arrowhead indicates the site where adaxial petal will develop. I, Aragoa cundinamarcensis. Gynoecium initiation. J, Aragoa x funzana. Upper view of apex inflorescence (sepals removed); the arrowhead shows the intercarpellary furrow. K, Aragoa cundinamarcensis. Lateral view of floral bud (sepals removed). L, Aragoa abietina. Lateral view of floral bud (sepals removed; adaxial petal on the right). M, Aragoa cleefii. Floral bud with margins of petals fusing (arrowhead; sepals removed; adaxial petal on the lower left). N, Aragoa x funzana. Cochlear aestivation of the calyx. O, Aragoa cundinamarcensis. Actinomorphic floral bud (sepals removed). $a=$ floral apex; $b=$ bract; $c=$ gynoecium; $e a=$ abaxial stamen; $e p=$ adaxial stamen; $p a=$ abaxial petal; $p l=$ lateral petal; $s 1=$ abaxial-lateral sepal; $s 2=$ adaxial-lateral sepal; $s 3=$ adaxial sepal; $t c=$ corolla tube; $x=$ inflorescence axis. Scale bars $=100 \mu \mathrm{m}$ in $A, B, D, E, H, I ; 50 \mu \mathrm{m}$ in $C, G ; 200$ $\mu \mathrm{m}$ in $F, J, K, M-O ; 500 \mu \mathrm{m}$ in $L$. 

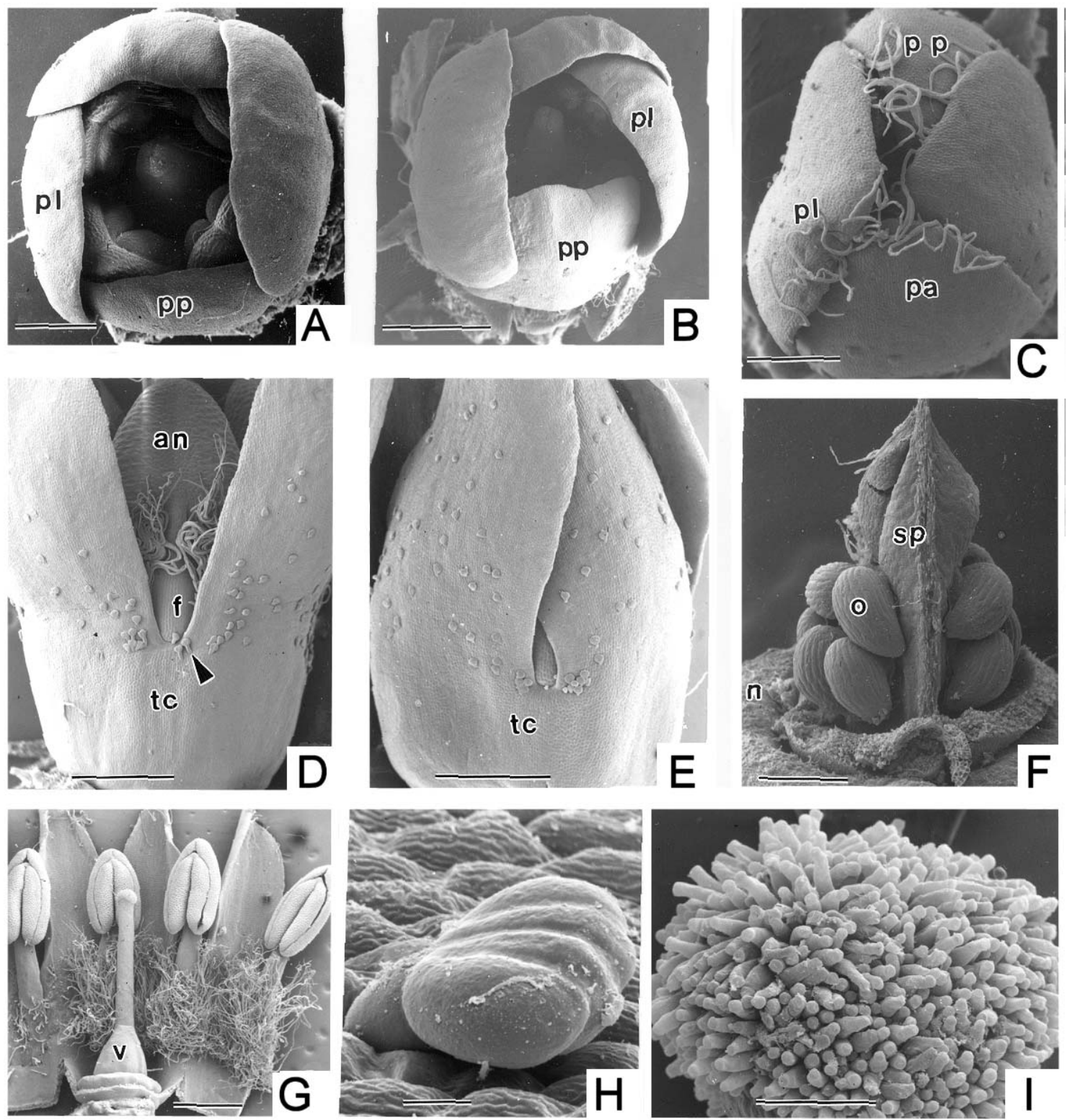

Fig. 4 Late floral development of Aragoa. A, B, Aragoa abietina. Upper view of mirror image of floral buds (sepals removed). C, Aragoa cleefii. Upper view of cochlear-ascendent corolla. D, E, Aragoa cleefii. Lateral view of the corolla; capitate hairs arrowed. F, Aragoa x funzana. Placental septum basally surrounded by a ringlike disk (ovary walls removed). G, Aragoa cleefii. Inner view of a mature flower. H, Aragoa x funzana. Capitate hair. I, Aragoa cleefii. Papillary stigma surface. $a n=$ anther; $f=$ filament; $n=$ nectarial disk; $o=$ ovule; $p a=$ abaxial petal; $p l=$ lateral petal; $p p=$ adaxial petal; $s p=$ placental septum; $t c=$ corolla tube; $v=$ ovary. Scale bars $=500 \mu \mathrm{m}$ in $A, C, E, F ; 1 \mathrm{~mm}$ in $B, D ; 2 \mathrm{~mm}$ in $G$; $20 \mu \mathrm{m}$ in $H ; 100 \mu \mathrm{m}$ in $I$.

carpels appear as a ringlike primordium (i.e., symplicate carpels; fig. 6D). Later development of the pistil was not followed in this species. Mature flowers show a bottle-shaped gynoecium basally surrounded by a ringlike nectariferous disc with glandular-ciliate border (not shown). The stigma is four lobed, narrowly capitate (not shown).

\section{Floral Development of Plantago}

Inflorescence. The developing spikes in Plantago show congested floral buds that develop acropetally (fig. 7A). Each floral bud is subtended by a bract that covers it even before organogenesis.

Calyx. Floral apices of Plantago are initially radially symmetrical until sepal emergence, which occurs unidirectionally; the initiation of the two abaxial-lateral sepal primordia is followed by the two adaxial-lateral ones (fig. $7 A$, $7 B$ ). There is no evidence of the emergence of a fifth adaxial primordium. Each calyx lobe soon becomes concave (fig. $7 B$ ); then, the calyx tube begins to be formed. The calyx tube remains short (fig. $7 E$ ). The abaxial-lateral calyx lobes are slighly larger than the adaxial-lateral ones (fig. 7C-7E), 

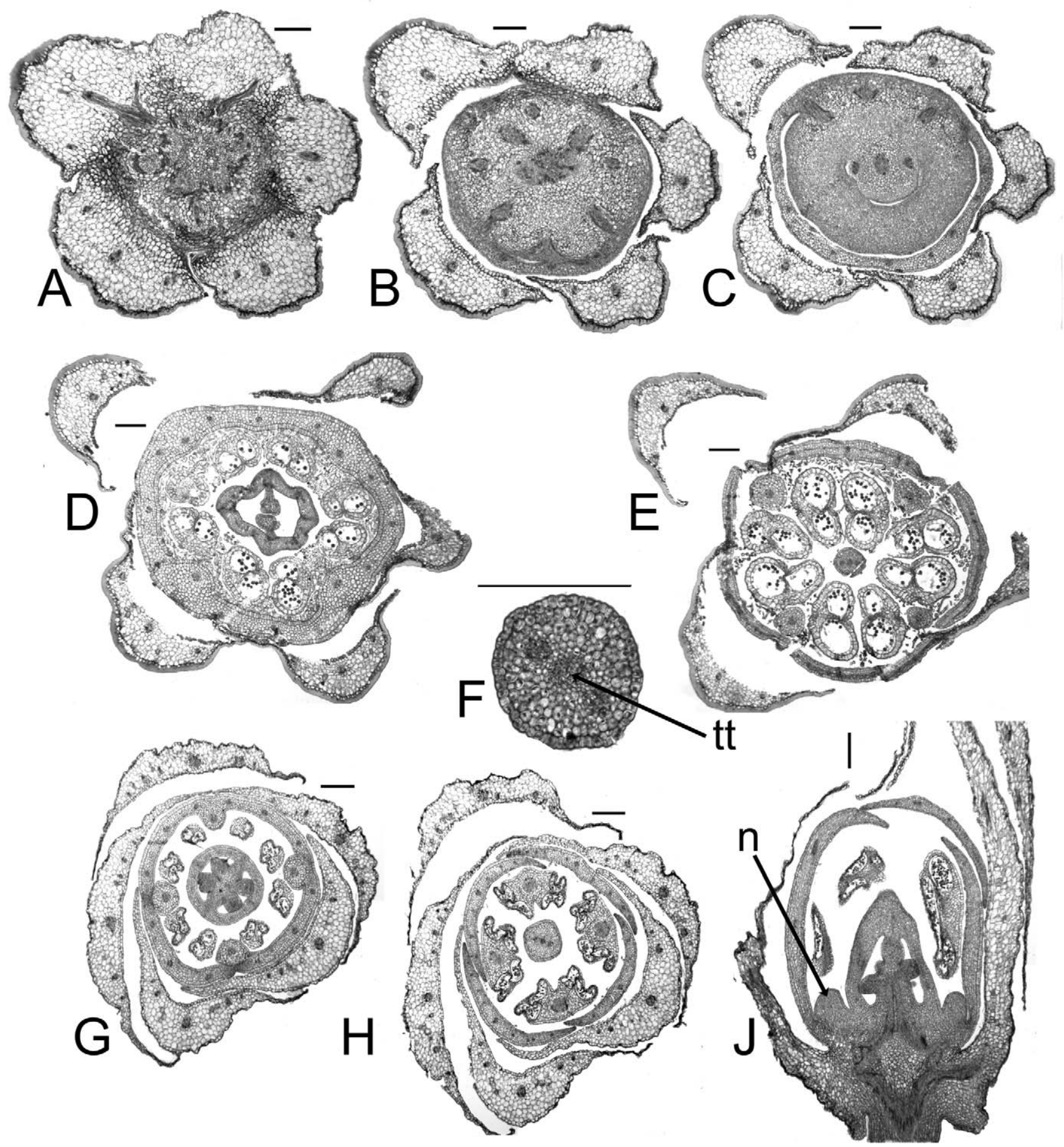

Fig. 5 LMs of flower sections. A-E, Aragoa cupressina, series of transverse sections (TS) through a single flower. F, Aragoa cupressina, TS style. G, H, Aragoa abietina, TS flower bud at preanthesis. J, Aragoa abietina, longitudinal sectional of flower bud at preanthesis. $n=$ nectariferous disc; $t t=$ stylar transmitting tissue. Scale bar $=100 \mu \mathrm{m}$.

showing a zygomorphic pattern. Pluricellular trichomes begin to develop on the outer surface (fig. 7D).

Androecium and corolla. The four stamens emerge simultaneously shortly before petal initiation (fig. 7A). Stamen primordia are opposite the sepals. The emergence of the petal primordia is unidirectional, from the abaxial to the adaxial side (fig. 7B). However, the adaxial petal becomes slightly larger than the others by mid-development (fig. 7C). There is no evidence that the adaxial petal is formed by the fusion of two petal primordia. The corolla lobes emerge independently 

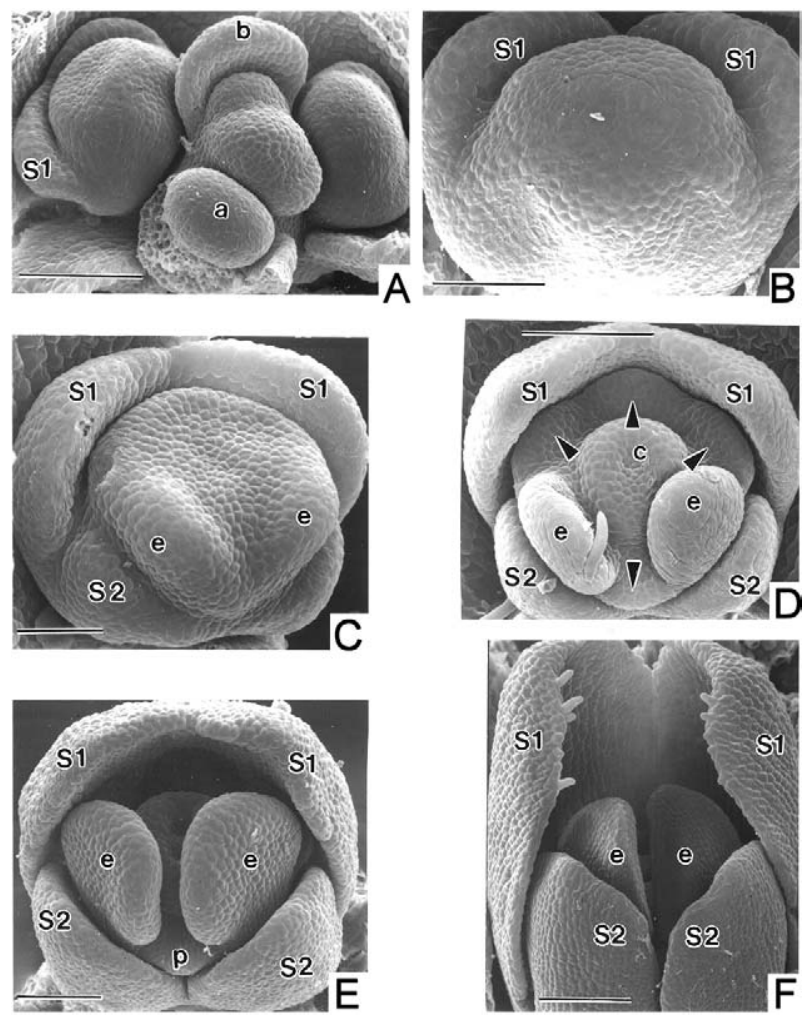

Fig. 6 Floral development of Heliohebe raoulii. A, Upper view of inflorescence apex with four floral buds. $B$, Frontal view of floral bud with two abaxial-lateral sepals already initiated. $C$, Floral bud with the two abaxial-lateral and two adaxial-lateral sepals; the two adaxial-lateral stamens start initiation. D, Floral bud with the four petals (arrowheads) initiated; gynoecium becomes evident. E, F, Midfloral bud with strongly zygomorphic calyx. $a=$ floral apex; $b=$ bract $; c=$ fused carpels; $e=$ stamen; $p=$ petal; $s 1=$ abaxiallateral sepal; $s 2=$ adaxial-lateral sepal. Scale bars $=100 \mu \mathrm{m}$ in $A$, $D-F ; 50 \mu \mathrm{m}$ in $B, C$.

(fig. 7B) and become interconnected by interprimordial growth with the alterning stamens, showing late sympetaly. By mid-development (fig. $7 C-7 F$ ), the corolla is actinomorphic, and the stamens are already differentiated in anther and filament (fig. 7F). Petal aestivation is imbricate because the abaxial petal is partially covered by the lateral and the adaxial ones (fig. 7G).

Gynoecium. Gynoecium development and gross shape of the mature pistil in Plantago major is essentially the same to that described in Aragoa (fig. 7A-7E).

\section{Discussion}

\section{Inflorescence}

Our results confirm Fernández-Alonso's (1995) report that the inflorescences of Aragoa are lateral, extremely condensed racemes (fig. 1). Plantago often has lateral spikes (see Weberling and Troll 1998 for a detailed description of inflorescences in Plantaginaceae). Therefore, inflorescences of Aragoa and Plantago are similar in that they are both lateral and polytelic. By contrast, Veronica and Hebe have predominantly polytelic inflorescences (cf. fig. 9 in Weberling and Troll 1998), but they are often terminal.

Flowers have been described as solitary in Angelonia Bonpl., Antirrhinum L., Aragoa, and Collinsia Nutt. (Meisner 1830-1843; Bentham 1846, 1876; Lemée 1929). However, they are primarily arranged in polytelic inflorescences, either as lateral (in Aragoa) or terminal racemes (in Angelonia, Antirrhinum, and Collinsia; see Wettstein 1895, their fig. 24).

Optimization of polytelic versus monotelic inflorescences in the Aragoa-Angelonia clade (not shown in fig. 8) indicates that polytelic inflorescences could be plesiomorphic. However, inflorescence architecture is unknown in genera such as Amphianthus and Hemiphragma, which makes interpretation of this character difficult in this clade. Inflorescences were described as monotelic in Tetranema Benth. ex Lindl. by Weber (1972), which would be autapomorphic for it. Lateral, polytelic inflorescences seem to be plesiomorphic in two subclades: ((((Aragoa + Plantago ) Veronica) Hemiphragma) Digitalis) Globularia) and ((Chelone + Collinsia) Tetranema). However, in these subclades, terminal polytelic inflorescences appear in Collinsia, Digitalis, and some species of Veronica. Littorella and Heliohebe (not sampled in Bello et al. 2002) have lateral and terminal polytelic inflorescences, respectively. In the remaining members of the Aragoa-Angelonia clade, solitary flowers appear independently at least twice in the clade Callitriche + Hippuris, in Gratiola, and in Bacopa. Furthermore, terminal polytelic inflorescences also appear independently in Angelonia and Antirrhinum. Inflorescence architecture is unknown in Amphianthus and Hemiphragma.

\section{Calyx}

In some groups of plants, the symmetry of the floral apex determines symmetry during early stages of floral organogenesis (Tucker 1984). This seems to occur in Digitalis and Heliohebe, which have zygomorphic floral apices before and after organogenesis (Singh 1979; Wunderlin 1992; fig. 6), and in Collinsia, which has radial floral apices and a simultaneous initiation of the sepals (Schrock and Palser 1967). However, the floral apices of Aragoa and Plantago are initially actinomorphic and become zygomorphic because of the abaxialadaxial emergence of the sepals (fig. $3 A-3 E$; table 3 ). A similar switch in symmetry of the floral apex has been observed in Angelonia, Antirrbinum, and Veronica (Srinivasan 1940; Singh and Jain 1979; Kampny et al. 1993) (table 2), although in Antirrhinum, zygomorphy is mainly expressed in the corolla and androecium (Endress 1999). During early and middevelopment in Aragoa, Digitalis, Heliohebe, Littorella, Plantago, and Veronica, the abaxial-lateral sepals are larger than either the adaxial sepal (if present) or the adaxial-lateral sepals (Payer 1857; Singh 1979; Kampny et al. 1993; Prakash and Singh 1997; fig. 6B-6D; table 3). Similar development is observed in the perianth (treated as calyx in Cronquist 1981; Takhtajan 1997) of Hippuris vulgaris (Leins and Erbar 1988).

A switch in symmetry during floral ontogeny was considered unusual by Tucker (1984) and Canne-Hilliker (1987) but has since been reported in a number of plants (Armstrong 

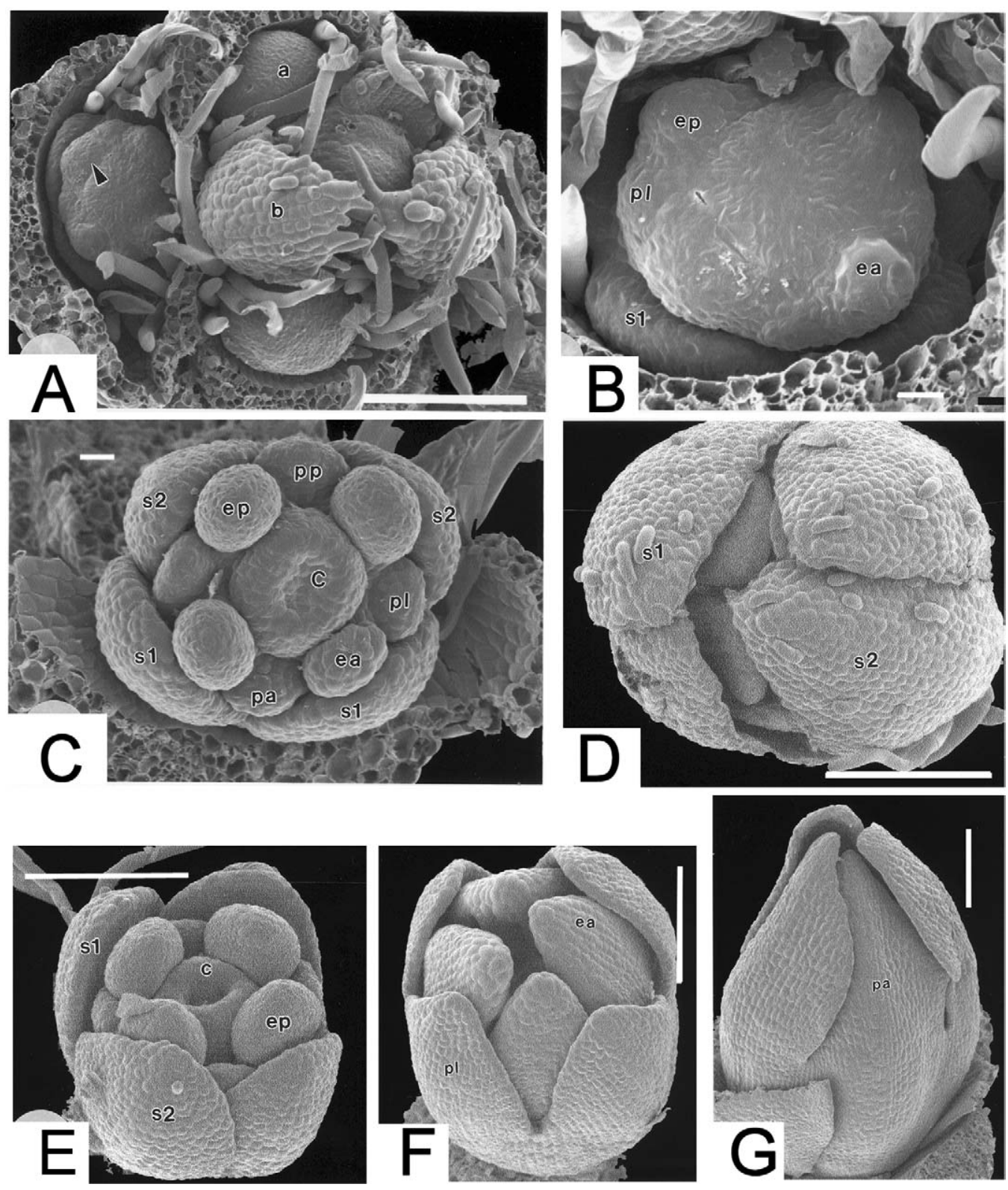

Fig. 7 Floral development of Plantago major. A, Upper view of an inflorescence; arrowhead on the left floral bud shows an abaxial-lateral stamen primordium. $B$, Floral bud with stamen and petal primordia; the adaxial petal primordia are not yet initiated. $C$, Midfloral development. $D, E$, Floral buds showing the zygomorphic calyx. $F, G$, Buds at preanthesis (sepals partially removed). $a=$ floral apex; $b=$ bract; $c=$ carpel; $e a=$ abaxial-lateral stamen; $e p=$ adaxial-lateral stamen; $p a=$ abaxial petal; $p l=$ lateral petal; $p p=$ adaxial petal; $s 1=$ abaxial-lateral sepal; $s 2$ = adaxial-lateral sepal. Scale bars $=100 \mu \mathrm{m}$ in $A, D-G ; 10 \mu \mathrm{m}$ in $B, C$.

and Douglas 1989; Endress 1999). Symmetry during early ontogeny is expressed by several traits as the order of initiation and the phyllotaxis of the floral organs, whereas in later stages, it is expressed by differential growth of the organs (Endress 1999). Similarly, it has been proposed that floral symmetry is affected during early development by the position of the floral buds in the inflorescence; for example, in some plants with actinomorphic flowers, initial development is strongly zygomorphic, especially in spikes or racemes (Endress 1999). Armstrong and Douglas (1989) suggested that zygomorphy produced only by early ontogeny would repre- sent primitive zygomorphy in Scrophulariaceae. This could also be applied to the unidirectional emergence of the sepals of Aragoa and related genera such as Plantago, which would represent ancestral zygomorphy of the calyx (fig. 9). The unidirectional development of the calyx is present independently in other groups of Scrophulariaceae s.l. such as Calceolaria L. (Ritterbusch 1976) and Lophospermum D. Don (=Asarina Miller; Payer 1857).

Synsepaly and pentamery are often correlated with zygomorphy of the calyx (Endress 1987). However, in Aragoa, in spite of early zygomorphy shown by the calyx, it becomes 


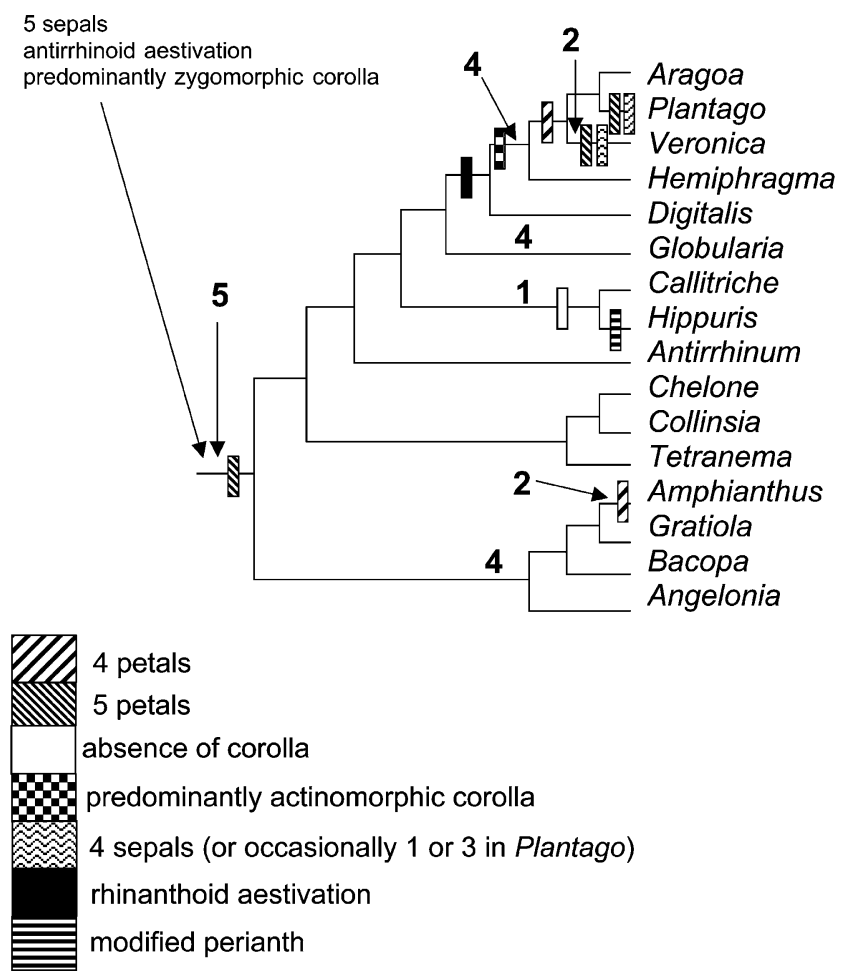

Fig. 8 Distribution of floral characters in the Aragoa-Angelonia clade, based on the topology achieved in the molecular analysis of Bello et al. (2002). Numbers above lines indicate number of stamens primordia that initiate in bud. Despite the presence of five petals in some species of Plantago and Veronica, presence of four petals is optimized as a synapomorphy of (((Aragoa + Plantago $)$ Veronica $)$ Hemiphragma), based on species-level phylogenies of Veronica and allies (Albach and Chase 2001) and Plantaginaceae (Rahn 1996; Rønsted et al. 2002), in which the basalmost taxa sampled have tetramerous corollas. This suggests that the pentamerous condition could be derived independently in Plantago and Veronica.

actinomorphic before anthesis; the calyx lobes become similar in size and shape, possibly because there is not a mechanical constriction on their edges as they have cochlear aestivation. This also occurs in Angelonia, Digitalis, and some species of Agalinis and Antirrhinum (Wettstein 1895, p. 89; Kampny and Canne-Hilliker 1987; Thompson 1988, pp. 62-66; table 2). However, in Heliohebe, Plantago, and Veronica, genera that primarily have four sepals, the calyx can remain zygomorphic in mature flowers (fig. 6F; table 2). Possibly a tetramerous calyx, with two abaxial-lateral and two adaxial-lateral sepals, allows a permanent zygomorphic symmetry of the calyx during floral development, although Littorella and some species of Plantago and Veronica, with four sepals, exhibit a radial symmetrical calyx (fig. $147 \mathrm{H}$ in Harms and Reiche 1895). Moreover, Endress (2003) suggested that in genera such as Plantago and Callitriche, merosity reduction of the perianth is related to a change from monosymmetry to polysymmetry.

In Aragoa and some species of Veronica, the adaxial sepal is smaller than the other sepals, whereas in Heliohebe, Littorella, Plantago, and other species of Veronica, it is completely suppressed (fig. 6; fig. 7A-7E; tables 2, 3). Taking into ac- count that the pentamerous condition of the calyx could be plesiomorphic in the Aragoa-Angelonia clade (fig. 8; see also Reeves and Olmstead 1998), the presence of four sepals in the latter four genera indicates a suppression of the adaxial sepal (table 3). This type of suppression in an ontogenetic sequence is considered as phase specific; i.e., it is restricted to one whorl only and does not alter subsequent ontogenetic stages (Hufford 1996). Therefore, calyx variation in members of the Aragoa-Angelonia clade includes pentamery (i.e., as in Antirrhinum, Aragoa, Collinsia, Digitalis, Hemiphragma, Globularia), tetramery (as in some species of Plantago and Veronica), trimery (as in some species of Plantago), and complete suppression or modification (as in Callitriche and Hippuris, respectively). Kampny and Dengler (1997) suggested that suppression of the adaxial sepal could be a synapomorphy of Veronica and allies, Pseudolysimachion (Koch) Opiz and Hebe group, with reversals to pentamery in several species of Veronica, in Chionohebe B. Briggs \& Ehrend., Paedorota L. and Paedorotella (Wulff) Kem.-Nat. However, in the Aragoa-Angelonia clade, the presence of four sepals appears independently in Plantago and Veronica and could be homoplastic in these genera (fig. 8).

\section{Androecium}

In most angiosperms, including Euasteridae, the sequence of formation of the floral whorls (calyx, corolla, androecium, and gynoecium) is centripetal (Endress 1994). However, in Aragoa, the corolla-androecium sequence of initiation is clearly inverted (fig. 3G; table 3 ). This change appears independently at least three times in the Aragoa-Angelonia clade: (1) in (Veronica (Plantago + Aragoa)) (Kampny et al. 1993; Kampny and Dengler 1997; Prakash and Singh 1997); (2) in Collinsia (cf. Schrock and Palser 1967); and (3) in Angelonia and Bacopa (cf. Srinivasan 1940; Safeeulla and Govindu 1950). The absence of comparative studies on Amphianthus, Chelone, Globularia, Gratiola, Hemiphragma, and Tetranema makes an interpretation of this character in the AragoaAngelonia clade difficult. Possibly this condition has evolved several times in various groups of Lamiales, although it could be considered as a secondary synapomorphy of the clade $(($ Aragoa + Plantago $)$ Veronica $)$. The emergence of the stamens before the petals has also been observed in other genera such as Besseya (Hufford 1995; Kampny and Dengler 1997), Calceolaria (Ritterbusch 1976), Phlox (Nishino 1983), Scrophularia marylandica (Schertz 1919), Synthyris (Hufford 1995; Kampny and Dengler 1997), Vadellia (Krishna Iyengar 1940), Plumbaginaceae (Prakash and Singh 1997), and Primulaceae (Duchartre 1844; Schertz 1919; Sattler 1962). Prakash and Singh (1997) suggested that in Plantago, this character could indicate a close relationship with Plumbaginaceae rather than with Scrophulariaceae s.l. However, the results of this study and other analyses of floral development in Scrophulariaceae s.l. allow interpretation of independent evolution of this character in different groups of Asteridae. Judd et al. (1999) suggested that the development of the androecium prior to the corolla could be a synapomorphy of Plantaginaceae; however, they included genera such as Digitalis in this family. In Digitalis, the emergence of the stamen primordia alternates with that of the petal primordia (Singh 
Table 2

Main Floral Features of Aragoa and Genera Included in the Aragoa-Angelonia Clade

\begin{tabular}{|c|c|c|c|c|c|c|c|c|c|c|c|c|c|c|}
\hline Genera & Inflorescences & $\begin{array}{c}\text { Floral } \\
\text { apex } \\
\text { symmetry }\end{array}$ & $\begin{array}{c}\text { Sepal } \\
\text { emergence }\end{array}$ & $\begin{array}{c}\text { Sepal } \\
\text { primordia }\end{array}$ & $\begin{array}{c}\text { Final } \\
\text { symmetry } \\
\text { of calyx }\end{array}$ & $\begin{array}{c}\text { Stamen } \\
\text { emergence }\end{array}$ & $\begin{array}{l}\text { Vestigial } \\
\text { stamens }\end{array}$ & $\begin{array}{c}\text { Fertile } \\
\text { stamens }\end{array}$ & $\begin{array}{c}\text { Petal } \\
\text { emergence }\end{array}$ & $\begin{array}{c}\text { Petal } \\
\text { primordia }\end{array}$ & Sympetaly & $\begin{array}{c}\text { Final } \\
\text { symmetry } \\
\text { of corolla }\end{array}$ & $\begin{array}{c}\text { Corolla } \\
\text { aestivation }\end{array}$ & References \\
\hline Amphianthus & Polytelic? & $?$ & ? & 5 & $?$ & $?$ & None & 2 & ? & 4 & ? & Bilateral & Antirrhinoid & $1,3,4,6,15$ \\
\hline Angelonia & $\begin{array}{l}\text { Polytelic } \\
\text { terminal }\end{array}$ & Radial & $\begin{array}{l}\text { Abaxial- } \\
\text { adaxial }\end{array}$ & 5 & Radial & $\begin{array}{l}\text { Abaxial- } \\
\text { adaxial }\end{array}$ & None & 4 & $?$ & 5 & $?$ & Bilateral & Antirrhinoid & $1,3,4,15,35$ \\
\hline Antirrbinum & $\begin{array}{l}\text { Polytelic } \\
\text { terminal }\end{array}$ & Radial & $\begin{array}{l}\text { Abaxial- } \\
\text { adaxial }\end{array}$ & 5 & $\begin{array}{r}\text { Bilateral } \\
\text { radial }\end{array}$ & $\begin{array}{l}\text { Abaxial- } \\
\text { adaxial }\end{array}$ & Adaxial & 4 & $\begin{array}{l}\text { Simulta- } \\
\text { neous? }\end{array}$ & 5 & Late & Bilateral & Antirrhinoid & $\begin{array}{l}1,2,3,4,7,8,13 \\
15,24,25,29,31 \\
32,35\end{array}$ \\
\hline Aragoa & $\begin{array}{r}\text { Polytelic } \\
\text { lateral }\end{array}$ & Radial & $\begin{array}{l}\text { Abaxial- } \\
\text { adaxial }\end{array}$ & 5 & Radial & $\begin{array}{r}\text { Simulta- } \\
\text { neous }\end{array}$ & None & 4 & $\begin{array}{c}\text { Abaxial- } \\
\text { adaxial }\end{array}$ & 4 & Late & Radial & Rhinanthoid & $\begin{array}{c}1,3,6,12 \\
15,38\end{array}$ \\
\hline Bacopa & $\begin{array}{l}\text { Solitary } \\
\text { flowers }\end{array}$ & ? & ? & 5 & ? & $?$ & None & 4 & ? & 5 & ? & Bilateral & Antirrhinoid & $1,3,4,15,34$ \\
\hline Callitriche & $\begin{array}{l}\text { Solitary } \\
\text { flowers }\end{array}$ & $?$ & ? & Absent & $\ldots$ & $?$ & None & $1-2$ & $\ldots$ & $\ldots$ & $\ldots$ & $\cdots$ & . & $\begin{array}{c}1,3,4,15 \\
17,32\end{array}$ \\
\hline Chelone & $\begin{array}{r}\text { Polytelic } \\
\text { lateral }\end{array}$ & $?$ & $?$ & 5 & ? & $?$ & Adaxial & 4 & $?$ & 5 & $?$ & Bilateral & Antirrhinoid & $\begin{array}{c}1,3,4,15 \\
18,32\end{array}$ \\
\hline Collinsia & $\begin{array}{l}\text { Polytelic } \\
\text { terminal }\end{array}$ & Radial & Simultaneous & 5 & Radial & $\begin{array}{r}\text { Simulta- } \\
\text { neous }\end{array}$ & Adaxial & 4 & ? & 5 & ? & Bilateral & Antirrhinoid & $1,3,4,15,27,32$ \\
\hline Digitalis & $\begin{array}{l}\text { Polytelic } \\
\text { terminal }\end{array}$ & $\begin{array}{l}\text { Radial or } \\
\text { bilateral }\end{array}$ & $\begin{array}{l}\text { Abaxial- } \\
\text { adaxial }\end{array}$ & 5 & Radial & $\begin{array}{l}\text { Abaxial- } \\
\text { adaxial }\end{array}$ & Adaxial & 4 & $\begin{array}{l}\text { Abaxial- } \\
\text { adaxial }\end{array}$ & 5 & Late & Bilateral & Rhinanthoid & $\begin{array}{l}1,3,4,15,28,32 \\
35,36\end{array}$ \\
\hline Globularia & $\begin{array}{r}\text { Polytelic } \\
\text { lateral }\end{array}$ & $?$ & ? & 5 & $?$ & $\begin{array}{l}\text { Abaxial- } \\
\text { adaxial }\end{array}$ & None & 4 & ? & 5 & ? & Bilateral & ? & $3,4,15,30$ \\
\hline Gratiola & $\begin{array}{l}\text { Solitary } \\
\text { flowers }\end{array}$ & ? & $?$ & 5 & Radial & $?$ & $\begin{array}{l}\text { Two } \\
\text { abaxial }\end{array}$ & 2 & ? & 5 & ? & Bilateral & Antirrhinoid & $1,3,4,15,35$ \\
\hline Heliohebe & $\begin{array}{l}\text { Polytelic } \\
\text { terminal }\end{array}$ & Bilateral & $\begin{array}{c}\text { Abaxial- } \\
\text { adaxial }\end{array}$ & 4 & Bilateral & $\begin{array}{r}\text { Simulta- } \\
\text { neous }\end{array}$ & None & 2 & $\begin{array}{c}\text { Abaxial- } \\
\text { adaxial }\end{array}$ & 4 & Late & Radial & Rhinanthoid & 38 \\
\hline Hemiphragma & $\begin{array}{l}\text { Solitary } \\
\text { flowers? }\end{array}$ & $?$ & $?$ & 5 & $?$ & $?$ & None & 4 & $?$ & 5 & ? & Radial & Rhinanthoid & $1,3,4,6,15$ \\
\hline Hippuris & $\begin{array}{l}\text { Solitary } \\
\text { flowers }\end{array}$ & $?$ & $\begin{array}{l}\text { Abaxial- } \\
\text { adaxial }\end{array}$ & $?$ & Radial & $\ldots$ & None & 1 & $\ldots$ & $\ldots$ & $\ldots$ & $\ldots$ & $\ldots$ & 5,30 \\
\hline Littorella & $\begin{array}{r}\text { Polytelic } \\
\text { lateral }\end{array}$ & $?$ & $\begin{array}{l}\text { Abaxial- } \\
\text { adaxial }\end{array}$ & 4 & Radial & $?$ & None & 4 & $?$ & 4 & $?$ & Radial & $?$ & $\begin{array}{l}6,10,11,12,15 \\
23,26\end{array}$ \\
\hline Plantago & $\begin{array}{r}\text { Polytelic } \\
\text { lateral }\end{array}$ & Radial & $\begin{array}{l}\text { Abaxial- } \\
\text { adaxial }\end{array}$ & 4 & $\begin{array}{l}\text { Radial, } \\
\text { bilateral }\end{array}$ & $\begin{array}{r}\text { Simulta- } \\
\text { neous }\end{array}$ & None & $(1-3) 4$ & $\begin{array}{c}\text { Abaxial- } \\
\text { adaxial }\end{array}$ & 4 & Late & $\begin{array}{l}\text { Radial, } \\
\quad \text { bilateral }\end{array}$ & Antirrhinoid & $\begin{array}{c}1,6,10,11,16,19 \\
20,21,22, \\
23,30,32,38\end{array}$ \\
\hline Tetranema & $\begin{array}{l}\text { Monotelic } \\
\text { lateral }\end{array}$ & $?$ & ? & 5 & ? & $?$ & Adaxial & 4 & ? & 5 & ? & Bilateral & Antirrhinoid & $1,3,4,15,33,35$ \\
\hline Veronica & $\begin{array}{l}\text { Polytelic } \\
\text { lateral and } \\
\text { terminal }\end{array}$ & Radial & $\begin{array}{l}\text { Abaxial- } \\
\text { adaxial }\end{array}$ & $5-4$ & $\begin{array}{l}\text { Radial, } \\
\quad \text { bilateral }\end{array}$ & $\begin{array}{r}\text { Simulta- } \\
\text { neous }\end{array}$ & None & 2 & $\begin{array}{c}\text { Abaxial- } \\
\text { adaxial }\end{array}$ & 4 & Late & $\begin{array}{l}\text { Radial, } \\
\quad \text { bilateral }\end{array}$ & Rhinanthoid & $\begin{array}{l}1,3,6,12,14,15 \\
16,26,32 \\
34,37\end{array}$ \\
\hline
\end{tabular}

Note. References for data in this table are as follows: 1 = Armstrong and Douglas 1989; 2 = Awasthi et al. 1984; 3 = Bentham 1846; $4=$ Bentham 1876; 5 = Cronquist 1981; 6 = Endlicher 1836-1840; 7 = Endress 1992; $8=$ Endress 1999; 9 = Fernández-Alonso 1995; 10 = Harms and Reiche 1895; 11 = Hoggard et al. 2003; 12 = Hong 1984; 13 = Kampny and Canne-Hilliker 1988; $14=$ Kampny et al. 1993; 15 = Lemeé 1929; 16 = Payer 1857; $17=$ Philbrick and Anderson 1992; $18=$ Pilger 1913; $19=$ Prakash and Singh 1997; $20=$ Rahn 1981; $21=$ Rahn 1984; $22=$ Rahn 1985; $23=$ Rahn 1996; $24=$ Ronse-Decraene 1992; $25=$ Ronse-Decraene and Smets 1994; $26=$ Saunders 1939; $27=$ Schrock and Palser 1967; $28=$ Singh 1979; $29=$ Singh and Jain 1979; $30=$ Takhtajan 1997; $31=$ Thompson 1988; $32=$ Walker-Larsen and Harder 2000; $33=$ Weber 1972; $34=$ Weberling and Troll 1998; $35=$ Wettstein $1895 ; 36=$ Wunderlin 1992; 37 = Yamazaki 1957; 38 = this study 
Table 3

Summary of Floral Development in Aragoa and Some Related Genera

\begin{tabular}{|c|c|c|c|c|c|c|c|c|c|c|c|}
\hline \multirow{3}{*}{$\begin{array}{l}\text { Taxa } \\
\text { Aragoa } \\
\text { Digitalis }\end{array}$} & \multicolumn{10}{|c|}{ Sequence of floral organ development } & \multirow{3}{*}{$\begin{array}{l}\text { References } \\
\text { This study } \\
\text { Chatin 1873; Singh } 1979 \\
\text { Wunderlin } 1992\end{array}$} \\
\hline & $\mathrm{Se}_{\mathrm{al}(2)}$ & $\mathrm{Se}_{\mathrm{pl}(2)}$ & $\mathrm{Se}_{\mathrm{p}(1)}$ & $\mathrm{St}_{(4)}$ & $\mathrm{Pe}_{\mathrm{a}(1)}$ & $\operatorname{Pe}_{\mathrm{al}(2)}$ & $\operatorname{Pe}_{\mathrm{ad}(1)}$ & & $*$ & $\mathrm{Ca}$ & \\
\hline & $\mathrm{Se}_{\mathrm{al}(2)}$ & $\mathrm{Se}_{\mathrm{pl}(2)}$ & $\mathrm{Se}_{\mathrm{p}(1)}$ & $\mathrm{Pe}_{\mathrm{a}(1)}$ & $\mathrm{St}_{\mathrm{al}(2)}$ & $\operatorname{Pe}_{\mathrm{al}(2)}$ & $\mathrm{St}_{\mathrm{pl}(2)}$ & $\operatorname{Pe}_{\mathrm{pl}(2)}$ & $\mathrm{Stm}_{\mathrm{ad}(1)}$ & $\mathrm{Ca}$ & \\
\hline Heliobebe & $\mathrm{Se}_{\mathrm{al}(2)}$ & $\mathrm{Se}_{\mathrm{pl}(2)}$ & $*$ & $\mathrm{St}_{(2)}$ & $P e_{a(1)}$ & $\operatorname{Pe}_{a l(2)}$ & $\operatorname{Pe}_{\mathrm{ad}(1)}$ & & $*$ & $\mathrm{Ca}$ & This study \\
\hline Plantago & $\mathrm{Se}_{\mathrm{al}(2)}$ & $\mathrm{Se}_{\mathrm{pl}(2)}$ & $*$ & $\mathrm{St}_{(4)}$ & $\mathrm{Pe}_{\mathrm{a}(1)}$ & $\operatorname{Pe}_{\mathrm{al}(2)}$ & $\mathrm{Pe}_{\mathrm{ad}(1)}$ & & $*$ & $\mathrm{Ca}$ & $\begin{array}{c}\text { Payer 1857; Prakash and } \\
\text { Singh 1997; this study }\end{array}$ \\
\hline Veronica & $\mathrm{Se}_{\mathrm{al}(2)}$ & $\mathrm{Se}_{\mathrm{pl}(2)}$ & $*$ & $\mathrm{St}_{(2)}$ & $\mathrm{Pe}_{\mathrm{a}(1)}$ & $\mathrm{Pe}_{\mathrm{al}(2)}$ & $\mathrm{Pe}_{\mathrm{ad}(1)}$ & & $*$ & $\mathrm{Ca}$ & $\begin{array}{l}\text { Payer 1857; Chatin 1873; } \\
\text { Erbar } 1991 \text {; Kampny } \\
\text { et al. } 1993\end{array}$ \\
\hline
\end{tabular}

Note. Sequence of events is from left to right. $\mathrm{a}=$ abaxial; $\mathrm{al}=$ abaxial-lateral; $\mathrm{Ca}=$ carpels; $\mathrm{p}=\mathrm{adaxial}$; Pe $=$ petals; $\mathrm{pl}=\mathrm{adaxial}-\mathrm{lateral}$; $\mathrm{Se}=$ sepals; $\mathrm{St}=$ stamens; Stm $=$ staminode. Numbers in parentheses indicate number of whorl parts. An asterisk indicates missing organs.

1979; Wunderlin 1992; table 3), which indicates the high residual lability of this character in closely related genera.

The emergence of the stamens is simultaneous in (Veronica (Plantago + Aragoa)), Collinsia (Schrock and Palser 1967) and Heliohebe (fig. 6C) and unidirectional (from abaxial to the adaxial side) in Angelonia (Srinivasan 1940), Antirrhinum (Endress 1999), Digitalis (Singh 1979; Wunderlin 1992), and Globularia (Chatin 1873). In the Aragoa-Angelonia clade the simultaneous emergence of the stamens appears independently at least twice and could be derived from a unidirectional pattern (table 2).

In Antirrhinum, Digitalis, and the ((Chelone + Collinsia) Tetranema) clade, five stamen primordia emerge, but the adaxial one remains rudimentary (Schrock and Palser 1967; Singh 1979; Endress 1999; Walker-Larsen and Harder 2000; table 2). In (Aragoa + Plantago), Angelonia, Bacopa, Globularia, Gratiola, and Hemiphragma only four stamens emerge, although in Gratiola the two abaxial are rudimentary (Chatin 1873; Wettstein 1895). This implies that the tetramerous androecial condition has evolved at least three times in the Aragoa-Angelonia clade (fig. 8). In Amphianthus, Heliohebe, and Veronica there are only two adaxial-lateral stamen primordia (fig. 6; table 2), a condition proposed as synapomorphic in Veroniceae (Kampny and Dengler 1997), which apparently evolved twice in the Aragoa-Angelonia clade. However, a plesiomorphic condition for tetramery cannot be ruled out because of the absence of information about androecial development in genera such as Bacopa, Gratiola, and Hemiphragma (see also Reeves and Olmstead 1998). The dimerous and/or tetramerous androecial condition has been proposed as derived from a pentamerous state in Asteridae, including Lamiales (Ronse Decraene 1992). However, in Lamiales, the tetramerous androecium is independently derived in different groups (Ronse Decraene 1992; Endress 1994, 1996; Walker-Larsen and Harder 2000), probably related to different constraints, including specific pollination syndromes, reduction in floral apex size, zygomorphy, and unilateral mechanical constraints during ontogeny (Delpino 1886; Ronse Decraene 1992; Kampny and Dengler 1997; Endress 1998).

\section{Corolla}

Petal primordia emerge in an abaxial-adaxial direction in all members of the clade $(($ Aragoa + Plantago $)$ Veronica $)$ and in Digitalis and Heliohebe (Kampny et al. 1993) (figs. 3H, $6 C, 7 B$; table 3 ). This character strongly suggests early zygomorphy in the corolla of Aragoa and Plantago, despite its predominantly actinomorphic symmetry during later development of the floral buds. The corollas in these genera become actinomorphic during enlargement as the tube grows uniformly and the lobes reach the same size and shape (fig. 3L, 3M; fig. 7F; fig. 9). The actinomorphic and tetramerous corolla of Aragoa is consistent with Endress's (2003) hypothesis that merosity reduction of the perianth is related to a change from monosymmetry to polysymmetry.

In Lamiales secondary actinomorphy occurs in a number of taxa (Endress 1999). The clade (((Aragoa + Plantago) Veronica) Hemiphragma), in which the corolla is actinomorphic at maturity, is nested within a group of genera with strongly zygomorphic corollas. Thus, within the Aragoa-Angelonia clade, the actinomorphic corolla in mature flowers could be interpreted as a derived condition. The zygomorphic corollas of some species of Plantago and Veronica could represent a symplesiomorphy. It has been found that mutation of the

\begin{tabular}{|c|c|c|c|c|c|c|}
\hline Whorl & \multicolumn{3}{|c|}{ Calyx } & \multicolumn{3}{|c|}{ Corolla } \\
\hline Stage & $\mathrm{O}$ & E & A & $\mathrm{O}$ & E & A \\
\hline Aragoa & 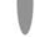 & V & & 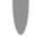 & & \\
\hline Plantago & 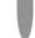 & 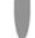 & & 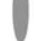 & & \\
\hline Veronica & 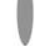 & 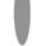 & & 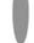 & & \\
\hline Digitalis & 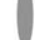 & 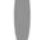 & & & & \\
\hline Antirrhinum & & 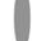 & & 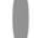 & & \\
\hline
\end{tabular}

Fig. 9 Differences in symmetry of calyx and corolla during different stages of floral development in Aragoa and related genera. $O=$ organogenesis; $E=$ enlargement; $A=$ anthesis; open circle $=$ actinomorphic; gray ellipse $=$ zygomorphic. 
genes CYCLOIDEA and DICHOTOMA in Antirrhinum produces polysymmetric flowers (Coen and Nugent 1994; Coen 1996; Luo et al. 1996, 1999), so it is possible that mutation of orthologous genes in related genera could be responsible for the secondary actinomorphy within the Aragoa-Angelonia clade.

The prevalent actinomorphic tetramerous corolla in Aragoa and Plantago during late stages of development and the tetramerous androecium are apparently synapomorphies of these two genera (fig. $3 M$, 3O; fig. $4 A$, 4B; fig. $7 B-7 G$ ). Although Hemiphragma possesses four stamens and an actinomorphic corolla at anthesis, its corolla is pentamerous. In Heliohebe and Veronica, the corolla is strongly zygomorphic during development, which results from the presence of three abaxial and one adaxial petal primordia and only two stamens (fig. 6C, 6D). If ontogeny frequently recapitulates phylogeny, differences in timing of a character state during development, such as changes of symmetry of calyx and corolla in Antirrhinum, Aragoa, Digitalis, Plantago, and Veronica (fig. 9), would indicate that zygomorphy of both whorls is the plesiomorphic condition for these genera. However, heterochronic shifts may well reflect complex developmental constraints and can undermine apparently straightforward ontogenetic sequence transformations (Hufford 1996).

A reduction from pentamerous to tetramerous corollas in Lamiales can occur by fusion of the adaxial-lateral petals. For example, in Digitalis (Wunderlin 1992), Orobanche, and Pedicularis (Meier-Weniger 1977), the adaxial corolla lobe is produced by two basally united primordia; the resulting corolla lobe is frequently broader than the others (Endress 1998). Assuming that a pentamerous corolla is ancestral in Lamiales (Endress 1994; Reeves and Olmstead 1998), reduction in petal number has occurred at least three times in the Aragoa-Angelonia clade: (1) in Callitriche and Hippuris, in which the corolla is totally absent (Leins and Erbar 1988); (2) in Amphianthus, with a tetramerous corolla; and (3) in ((Aragoa + Plantago) Veronica), also with tetramerous corollas. During floral development of Aragoa, Plantago, and Veronica, there is no direct evidence of fusion of two primordia to form the adaxial petal, although the adaxial petal primordium is slightly broader than the others in early development of Aragoa (fig. 3H), Plantago (fig. 7C; see also Eichler 1878; Saunders 1939; Endress 1998), and Veronica (Hufford 1992; Kampny et al. 1993). The tetramerous corolla could be synapomorphic for the clade ((Aragoa + Plantago) Veronica) (fig. 8). The presence of five petals in some species of Plantago (Rahn 1996) and Veronica (Saunders 1939; Yamazaki 1957) could be homoplastic because species-level phylogenies of these genera show that their basalmost members have tetramerous corollas (Rahn 1996; Albach and Chase 2001; Rønsted et al. 2002).

Within the Aragoa-Angelonia clade, late sympetaly occurs in Antirrhinum, Aragoa, Collinsia, Globularia, Digitalis, Plantago, and Veronica (Schrock and Palser 1967; Singh 1979; Erbar 1991; this study). In these genera, the petal primordia emerge independently and become interconnected by interprimordial growth of the alternate stamens (fig. $3 \mathrm{~K}-3 \mathrm{M}$ ). However, there are some differences between the late sympetaly of Digitalis and Veronica; Erbar (1991) showed that in Digitalis the two upper petals arise separately and fuse later, whereas in Veronica sympetaly occurs during formation of the upper and lower lips. Erbar (1991) suggested that in these variations, the original condition may become blurred by events such as dorsiventrality and abortion in the androecium. In order to analyze sympetaly in a phylogenetic context, this character needs to be carefully studied in other genera of Aragoa-Angelonia clade such as Amphianthus, Angelonia, Bacopa, Chelone, Collinsia, Gratiola, and Tetranema.

Corolla aestivation has been considered an important diagnostic character in Scrophulariaceae s.l. (Pennell 1935) because in most Antirrhinoideae, the adaxial lobes are external, whereas in Rhinanthoideae, the abaxial lobes are external in bud. Armstrong and Douglas (1989) showed that this character is evident even during early ontogeny; stronger growth occurs in the adaxial lobes in Antirrhinoideae and in the abaxial lobes in Rhinanthoideae. As Aragoa exhibits rhinanthoid aestivation (fig. $4 A-4 C$ ), it has traditionally been included in the latter subfamily (cf. Takhtajan 1997). The distribution of this character in the Aragoa-Angelonia clade shows that antirrhinoid aestivation occurs in most of the basal genera (Amphianthus, Angelonia, Antirrhinum, Bacopa, Chelone, Collinsia, Globularia, and Gratiola) (fig. 8; table 2). Thus, rhinanthoid aestivation could be a synapomorphy of the clade (Digitalis (Hemiphragma (Veronica (Plantago + Aragoa)))), although this character needs detailed ontogenetic study, particularly in Plantago.

\section{Gynoecium}

The general pattern of gynoecial structure and development seems to be relatively uniform in Lamiales (Kampny and Canne-Hilliker 1988; Kampny et al. 1993; Endress 1994). The unilocular gynoecium (in Gratiola, Hippuris, and some species of Plantago) and tetralocular gynoecium (present in Callitriche by formation of a false septum; see Lemée 1929; Leins and Erbar 1988) are apomorphic in the AragoaAngelonia clade, whereas the bilocular gynoecium, which occurs in Aragoa, is plesiomorphic. Seeds of Aragoa and Plantago are remarkably similar because they are flattened, winged, and reticulate (M. A. Bello, personal observation; cf. also Fernández-Alonso 1995 and Rahn 1996), thus providing a set of possible synapomorphies between the two genera. As for the ringlike nectariferous disk with glandular-ciliate border found in Heliohebe raoulii, it is remarkably similar to that found in Heliohebe hulkeana (F. Muell.) Garn.-Jones (cf. fig. $1 A$ in Garnock-Jones 1993).

\section{Interspecific Differences}

Fernández-Alonso (1995) found that gross morphological characters of the mature flowers of Aragoa are useful to propose five species groups. The species examined here represent three of these groups: Aragoa abietina belongs to the Abietina group; Aragoa cleefii and Aragoa cupressina belong to the Cuppressina group; and Aragoa cundinamarcensis belongs to the Lycopodioides group. However, we did not observe differences in early development that would suggest deep ontogenetic differentiation between these species groups. The slight differences that we have detected are evident only during late stages, when the corolla reaches its definite shape and indumentum; corollas of A. cupressina, A. cleefii, and A. 
abietina are subrotaceous and have a dense indumentum on the inner side of the tube, whereas in A. cundinamarcensis, it is rotaceous with a glabrous tube. This observation is consistent with Tucker's $(1984,1997)$ theory that floral characters that are variable at a suprageneric level often arise during early stages of development, whereas those that are variable at generic or infrageneric levels emerge during medium and late developmental stages. In other genera of Lamiales such as Agalinis Raf., the appearance of characters that are variable at a specific level also occurs during late development (Kampny and Canne-Hilliker 1987; see also Armstrong and Douglas 1989 for further examples). However, this theory requires more rigorous testing; such hierarchical levels are artificial and may not be equivalent in different groups.

\section{Floral Vasculature}

Floral vascularization provides contradictory evidence in members of the Aragoa-Angelonia clade. In some species of Veronica and Veronicastrum, the upper lip of the tetramerous corolla is irrigated by two traces, which could be taken as evidence that this lip is produced from two fused petal primordia (Saunders 1933; Yamazaki 1957; Nishino 1983;
Armstrong 1985). By contrast, in Digitalis, the staminode is not vascularized (Henslow 1890), which indicates that, in this case, the vasculature disappeared before the loss of the external organ. Floral vascularization of Aragoa does not show vestigial traces of lost floral parts (fig. 5). It seems that the reduction of vascular traces versus external organs is distinct in different taxa (Ronse-Decraene 1992). This requires that such reductions be evaluated with care (Sattler 1973), especially in Lamiales, in which floral synorganization of sepals, petals, and stamens is expressed in diverse combinations of reduction and fusion.

\section{Acknowledgments}

We thank the staff of the Micromorphology Section, Jodrell Laboratory, Royal Botanic Gardens, Kew, especially Chrissie Prychid and Peter Gasson, for their kind assistance during the development of this study. We are grateful to J. Armstrong, Larry Hufford, and an anonymous reviewer for their comments on the manuscript. We also thank the Kew Latin American Research Fellowship program for a grant awarded to Favio González, which partly financed this study.

\section{Literature Cited}

Albach DC, MW Chase 2001 Paraphyly of Veronica (Veroniceae; Scrophulariaceae): evidence from the internal transcribed spacer (ITS) sequences of nuclear ribosomal DNA. J Plant Res 114:9-18.

Armstrong JE 1985 The delimitation of Bignoniaceae and Scrophulariaceae based on floral anatomy, and the placement of problem genera. Am J Bot 72:755-766.

Armstrong JE, AW Douglas 1989 The ontogenetic basis for corolla aestivation in Scrophulariaceae. Bull Torrey Bot Club 116: 378-389.

Awasthi DK, V Kumar, YS Murty 1984 Flower development in Antirrhinum majus L. (Scrophulariaceae) with a comment upon corolla tube formation. Bot Mag Tokyo 97:13-22.

Bello MA, MW Chase, R Olmstead, N Rønsted, D Albach 2002 The páramo endemic Aragoa is the sister genus of Plantago (Plantaginaceae; Lamiales): evidence from plastid $r b c \mathrm{~L}$ and nuclear ribosomal ITS sequence data. Kew Bull 57:585-597.

Bentham G 1846 Scrophulariaceae. Pages 186-586 in A De Candolle, ed. Prodromus systematis naturalis regni vegetabilis. Vol 10. Masson, Paris.

1876 Scrophularineae. Pages 913-980 in G Bentham, JD Hooker, eds. Genera plantarum. Vol 2. Lovell Reeve, London.

Canne-Hilliker JM 1987 Patterns of floral development in Agalinis and allies (Scrophulariaceae). II. Floral development of Agalinis densiflora. Am J Bot 74:1419-1430.

Chatin M 1873 Sur l'organogénie de l'androcée del Labiées, des Globulariées et des Scrophularinées. Bull Soc Bot Fr 28:41-46.

Coen ES 1996 Floral symmetry. EMBO (Eur Mol Biol Organ) J 15: 6777-6788.

Coen ES, JM Nugent 1994 Evolution of flowers and inflorescences. Development 120(suppl):107-116.

Cronquist A 1981 An integrated system of classification of flowering plants. Columbia University Press, New York. 1262 pp.

Delpino F 1886 Zigomorfia florale e sue cause. Malpighia 1:245-262.

Don D 1835 On the characters of certain groups of the class Personatae. Edinb New Philos J 19:108-114.
Donoghue MJ, RH Ree, DA Baum 1998 Phylogeny and the evolution of flower symmetry in the Asteridae. Trends Plant Sci 3:311-317.

Duchartre MP 1844 Sur l'organogénie de la fleur et en particulier de l'ovarie. Ann Sci Nat Bot 8:279-297.

Eichler AW 1878 Blüthendiagramme. Engelmann, Leipzig. 575 pp.

Endlicher S 1836-1840 Scrophularinae. Pages 670-696 in Genera plantarum secundum ordines naturales disposita. Beck, Vindobonae.

Endress PK 1987 Floral phyllotaxis and floral evolution. Bot Jahrb Syst 108:417-438.

1992 Evolution and floral diversity: the phylogenetic surroundings of Arabidopsis and Antirrhinum. Int J Plant Sci 153:106-122.

1994 Diversity and evolutionary biology of tropical flowers. Cambridge University Press, Cambridge. 511 pp.

1996 Homoplasy in angiosperm flowers. Pages 303-325 in MJ Sanderson, L Hufford, eds. Homoplasy: the recurrence of similarity in evolution. Academic Press, London.

1998 Antirrhinum and Asteridae: evolutionary changes of floral symmetry. Symp Soc Exp Biol 51:133-140.

1999 Symmetry in flowers: diversity and evolution. Int J Plant Sci 160(suppl):S3-S23.

2003 Morphology and angiosperm systematics in the molecular era. Bot Rev 68:545-570.

Erbar C 1991 Sympetaly: a systematic character? Bot Jahrb Syst 112: 417-451.

Fernández-Alonso JL 1991 Nueva especie y comentario morfológicos y fitogeográficos en el género Aragoa H.B.K. (Scrophulariaceae). Caldasia 16:301-310.

1993 Novedades taxonómicas en Aragoa H.B.K. (Scrophulariaceae) y sinopsis del género. An Jard Bot Madrid 51:73-96.

1995 Scrophulariaceae: Aragoeae. Flora de Colombia, no. 16. Universidad Nacional de Colombia, Bogotá.

Garnock-Jones PJ 1993 Phylogeny of the Hebe complex (Scrophulariaceae). Aust Syst Bot 6:457-479.

Hallier H 1903 Ueber die Abgrenzung und Verwandtschaft der einzelnen Sippen bei den Scrophularineen. Bull Herb Boiss 3: 181-207. 
Harms H, Reiche KF 1895 Plantaginaceae. Pages 363-373 in A Engler, K Prantl, eds. Die natürlichen Pflanzenfamilien. Vol 4, no. 3b. Engelmann, Leipzig.

Henslow G 1890 On the vascular systems of floral organs, and their importance in the interpretation of the morphology of flowers. Linn J Bot 28:151-197.

Hoggard RK, PJ Kores, M Molvray, GD Hoggard, DA Broughton 2003 Molecular systematics and biogeography of the amphibious genus Littorella (Plantaginaceae). Am J Bot 90:429-435.

Hong D-Y 1984 Taxonomy and evolution of the Veroniceae (Scrophulariaceae) with special reference to palynology. Opera Bot 75 : $1-60$.

Hufford L 1992 Floral structure of Besseya and Synthyris (Scrophulariaceae). Int J Plant Sci 153:217-229.

1995 Patterns of ontogenetic evolution in perianth diversification of Besseya (Scrophulariaceae). Am J Bot 82:655-680.

1996 Ontogenetic evolution, clade diversification, and homoplasy. Pages 271-301 in MJ Sanderson, L Hufford, eds. Homoplasy: the recurrence of similarity in evolution. Academic Press, London.

Jensen S, N Rønsted, MA Bello 2003 Aragoside and iridoid glucosides from Aragoa cundinamarcensis. Phytochemistry 64: 529-533.

Judd W, CS Campbell, EA Kellogg, PF Stevens 1999 Plant systematics: a phylogenetic approach. Sinauer, Sunderland, Mass.

Kampny CM, JM Canne-Hilliker 1987 Patterns of floral development in Agalinis and allies (Scrophulariaceae). I. Floral development of Agalinis fasciculata and A. tenuifolia. Can J Bot 65: 2255-2262.

- 1988 Aspects of floral development in Scrophulariaceae, striking early differences in three tribes. Pages 147-157 in P Leins, $S$ Tucker, PK Endress, eds. Aspects of floral development. Cramer, Berlin.

Kampny CM, NG Dengler 1997 Evolution in flower shape in Veroniceae. Plant Syst Evol 205:1-25.

Kampny CM, TA Dickinson, NG Dengler 1993 Quantitative comparison of floral development in Veronica chamaedrys and Veronicastrum virginicum (Scrophulariaceae). Am J Bot 80: 449-460.

Krishna Iyengar CV 1940 Development of embryo-sac and endosperm-haustoria in some members of Scrophularinae. IV. Vandellia hirsuta Ham. and V. scabra Benth. J Indian Bot Soc 18: 179-189.

Leins P, C Erbar 1988 Some remarks on flower development and systematic position of the water plants Callitriche, Hippuris and Hydrostachys. Beitr Biol Pflanz 63:157-178.

Lemée A 1929 Dictionnaire descriptif et synonymique des genres de plantes phanerogames. Brest, Paris.

Luo D, R Carpenter, L Copsey, C Vincent, J Clark, E Coen 1999 Control of organ asymmetry in flowers of Antirrhinum. Cell 99: 367-376.

Luo D, R Carpenter, L Vincent, L Copsey, E Coen 1996 Origin of floral asymmetry in Antirrhinum majus. Nature 383:794-799.

Meier-Weniger E 1977 Die Morphogenese der Blüte von Pedicularis recutita L. (Scrophulariaceae). Ber Dtsch Bot Ges 90:61-75.

Meisner CF 1830-1843 Plantarum vascularium genera secundum ordines naturales digesta eurumque differentiae et affinitates. Libraria Weidmannia, Lipsiae.

Neal PR, A Dafni, M Giurfa 1998 Floral symmetry and its role in plant-pollinator systems: terminology, distribution and hypotheses. Annu Rev Ecol Syst 29:345-373.

Nilsson S, D-Y Hong 1993 The taxonomic significance of Aragoapollen (Scrophulariaceae). Opera Bot 121:275-278.

Nishino E 1983 Corolla tube formation in the Tubiflorae and Gentianales. Bot Mag Tokyo 96:223-243.
Olmstead RG, CW dePamphilis, AD Wolfe, ND Young, WJ Elisons, P Reeves 2001 Disintegration of the Scrophulariaceae. Am J Bot 88: 348-361.

Payer JB 1857 Traité d'organogénie de la fleur. Masson, Paris.

Pennell FW 1935 The Scrophulariaceae of eastern temperate North America. Acad Nat Sci Phila Monogr 1.

1937 Taxonomy and distribution of Aragoa and its bearing on the geological history of the Northern Andes. Proc Acad Nat Sci Phila 89:425-432.

Philbrick CT, GJ Anderson 1992 Pollination biology of Callitrichaceae. Syst Bot 17:282-292.

Pilger R 1913 Biologie und Systematik von Plantago Novorbis. Bot Jahrb Syst 50:171-215.

Prakash I, V Singh 1997 Floral organogenesis of Plantago major L. with special reference to the systematic position of family Plantaginaceae. J Indian Bot Soc 76:275-280.

Rahn K 1981 Plantago ser. Sericeae, a taxonomic revision. Nord J Bot 1:297-323.

1984 Plantago sect. Oliganthos in southern South America, a taxonomic revision. Nord J Bot 4:601-627.

1985 Plantago sect. Carpophorae, a taxonomic study. Nord J Bot 5:143-151.

1996 A phylogenetic study of the Plantaginaceae. Bot J Linn Soc 120:145-198.

Reeves PA, RG Olmstead 1998 Evolution of novel morphological and reproductive traits in a clade containing Antirrhinum majus (Scrophulariaceae). Am J Bot 85:1047-1056.

Ritterbusch A 1976 Die Organopoiëse der Blüte von Calceolaria tripartita R. et P. (Scrophulariaceae). Bot Jahrb Syst 95:267-320.

Ronse-Decraene L-P 1992 The androecium of the Magnoliophytina: characterization and systematic importance. PhD diss. Katholieke Universiteit Leuven, Belgium.

Ronse-Decraene L-P, EF Smets 1994 Merosity in flowers: definition, origin and taxonomic significance. Plant Syst Evol 191:83-104.

Rønsted N, MW Chase, D Albach, MA Bello 2002 Phylogenetic relationships within Plantago (Plantaginaceae): evidence from nuclear ribosomal ITS and plastid trnL-F sequence data. Bot J Linn Soc 139:323-338.

Rouy G 1909 Conspectus des tribus et des genres de la famille des Scrophulariacées. Rev Gen Bot 21:194-207.

Rudall PJ, RM Bateman 2003 Evolutionary change in flowers and inflorescences: evidence from naturally occurring terata. Trends Plant Sci 8:76-82.

Safeeulla KM, HC Govindu 1950 Development of the female gametophyte and endosperm in Bacopa latoniana. Lloydia 13: 179-182.

Sattler R 1962 Zur frühen Infloreszenz und Blütenentwiklung der Primulales sensu lato mit besonderer Berücksichtigung der Stamen-Petalum-Entwicklung. Bot Jahrb Syst 81:358-396.

1973 Organogenesis of flowers, a photographic text-atlas. University of Toronto Press, Toronto. 207 pp.

Saunders E 1933 A study of Veronica from the viewpoint of certain floral characters. J Linn Soc Bot 49:453-493.

1939 Floral morphology: a new outlook with special reference to the interpretation of the gynoeceum. Vol 2. Heffer, Cambridge. 609 pp.

Schertz FM 1919 Early development of floral organs and embryonic structures of Scrophularia marylandica. Bot Gaz 68: 441-451.

Schrock GF, B Palser 1967 Floral development, anatomy and embryology of Collinsia heterophylla with some notes on ten species of Collinsia and on Tonella tenella. Bot Gaz 128: 83-104.

Singh V 1979 Early floral development in Digitalis purpurea. Phytomorphology 29:239-245. 
Singh V, SK Jain 1979 Floral organogenesis in Antirrhinum majus (Scrophulariaceae). Proc Indian Acad Sci Sect B 88:183-188.

Srinivasan VK 1940 Morphological and cytological studies in the Scrophulariaceae. II. Floral morphology and embryology of Angelonia grandiflora C. Morr. and related genera. J Indian Bot Soc 19:197-222.

Takhtajan A 1997 Diversity and classification of flowering plants. Columbia University Press, New York.

Thieret JW 1967 Supraspecific classification in the Scrophulariaceae: a review. Sida 3:87-106.

Thompson D 1988 Systematics of Antirrhinum (Scrophulariaceae) in the New World. Syst Bot Monogr 22:1-142

Tucker S 1984 Origin of symmetry in flowers. Pages 351-395 in RA White, WC Dickison, eds. Contemporary problems in plant anatomy. Academic Press, New York.

1997 Floral evolution, development and convergence: the hierarchical-significance hypothesis. Int J Plant Sci 158(suppl): S143-S161.

von Humboldt A, A Bonpland, CS Kunth 1819 Bignoniaceae. Pages 131-159 in Nova genera et species plantarum. Vol 3. Lutetiae Parisiorum: Sumtibus Librariae Graeco-Latino-Germanica, Paris.
Walker-Larsen J, LD Harder 2000 The evolution of staminodes in angiosperms: patterns of stamen reduction, loss, and functional re-invention. Am J Bot 87:1367-1384.

Weber A 1972 Der Blütenstand von Tetranema mexicanum Benth. (Scrophulariaceae) und seine Beziehungen zu Jenen der Gesneriaceen. Mit Bot Linz 4:27-43.

Weberling F, W Troll 1998 Die Infloreszenzen, Typologie und Stellung im Aufbau des Vegetationskörpers. Band II: teil 2. Gustav Fischer, Jena. 483 pp.

Wettstein R 1895 Scrophulariaceae. Pages 39-107 in A Engler, K Prantl, eds. Die natürlichen Pflanzenfamilien. Vol 4. Engelmann, Leipzig.

Wunderlin U 1992 Untersuchungen zur vergleichenden Entwicklungsgeschichte von Scrophulariaceen-Blüten: Die Entwicklung der Blüten von Digitalis lantana, Digitalis lutea, Digitalis isabelliana, Erinus alpinus, Wulfenia baldacci, Alonsoa warscewiczii, und Nemesia capensis. Diss Bot 188. Cramer, Berlin.

Yamazaki T 1957 Taxonomical and phylogenetical studies of Scrophulariaceae-Veroniceae with special reference to Veronica and Veronicastrum in Eastern Asia. J Fac Sci Univ Tokyo Sect III Bot 7: 91-162. 